(c) American Dairy Science Association, 2007.

\title{
Subclinical and Clinical Mastitis in Heifers Following the Use of a Teat Sealant Precalving
}

\author{
K. I. Parker, ${ }^{\star 1}$ C. Compton, ${ }^{*}$ F. M. Anniss, ${ }^{\star}$ A. Weir, $†$ C. Heuer, $\ddagger$ and S. McDougall \\ *Animal Health Centre, PO Box 21 Morrinsville, New Zealand \\ †Eltham District Veterinary Services, PO Box 24, Eltham, New Zealand \\ $\ddagger$ Epicentre, Massey University, Palmerston North, New Zealand
}

\section{ABSTRACT}

This study investigated the effect in heifers of infusion of a bismuth subnitrate teat-canal sealant and bacterial intramammary infection (IMI) precalving on prevalence of postcalving IMI and incidence of clinical mastitis in the first $2 \mathrm{wk}$ postcalving. Glands $(\mathrm{n}=1,020)$ from heifers $(\mathrm{n}=255)$ in 5 seasonally calving, pasturefed dairy herds were randomly assigned within heifer to 1 of 4 treatment groups (no treatment; mammary gland secretion collection; infusion of a teat sealant; or sample collection with infusion of teat sealant). Heifers within a herd were enrolled on one calendar day, $31 \mathrm{~d}$ on average before the planned start of the seasonal calving period. Duplicate milk samples were collected from each gland within $4 \mathrm{~d}$ after calving for bacterial culture. Herd owners collected duplicate milk samples, before treatment, for bacterial culture from glands they defined as having clinical mastitis. The gland prevalence of IMI precalving was $15.5 \%$ and did not differ between herds. Bacteria isolated precalving included coagulase-negative staphylococci (76.9\% of all bacteriologically positive samples), Streptococcus uberis (14.1\%), Staphylococcus aureus (5.1\%), Corynebacterium spp. (3.8\%), and others $(0.1 \%)$. The presence of an IMI precalving increased the risk of an IMI postcalving 3.6-fold and the risk of clinical mastitis 4-fold, relative to no IMI precalving. Infusion of the teat sealant reduced the risk of postcalving IMI due to Strep. uberis by $84 \%$, and of clinical mastitis by $68 \%$. Sampling the glands precalving had no effect on postcalving IMI or on clinical mastitis incidence. Use of an internal teat canal sealant in heifers precalving may be a useful tool for reducing the risk of subclinical and clinical mastitis in heifers.

Key words: mastitis, Streptococcus uberis, heifer, teat sealant

Received April 14, 2006.

Accepted August 3, 2006.

${ }^{1}$ Corresponding author: kparker@ahc.co.nz

\section{INTRODUCTION}

Peripartum clinical mastitis incidence is greater in heifers than in older herd mates (Barkema et al., 1998). The epidemiology of mastitis peripartum may be different in heifers from cows, because heifers have not been exposed to the milking process and its associated mastitis risk factors. Risk factors for IMI or clinical mastitis in heifers are not well defined in pasture-based dairy systems and specific recommendations for control of mastitis in heifers are limited in these systems.

Intramammary infection and clinical mastitis in heifers in early lactation result in long-term production loss (Oliver et al., 2003; De Vleigher et al., 2005a), an increased risk of clinical mastitis in the subsequent lactation, and an increased risk of premature removal from the herd (Rupp et al., 2000; Waage et al., 2000; De Vleigher et al., 2005b).

Intramammary infections have been detected as early as 9 mo precalving in heifers (Trinidad et al., 1990a). Prevalence of IMI increases as calving approaches (Oliver and Mitchell, 1983; Aarestrup and Jensen, 1997). Estimates of prevalence precalving range from 20 to 97\% (Meaney, 1981; Trinidad et al., 1990a; Myllys, 1995). The peripartum period is associated with increased risk of new IMI and clinical mastitis relative to earlier in gestation, likely to be associated with the transition into lactation (Aarestrup and Jensen, 1997).

In intensive dairy systems the bacteria isolated from the mammary glands of heifers peripartum include Staphylococcus aureus, coagulase-negative Staphylococcus, Streptococcus uberis, Streptococcus dysgalactiae, Corynebacterium spp., and coliforms (Oliver and Mitchell, 1983; Trinidad et al., 1990a; Fox et al., 1995). Environmental factors affect the type and prevalence of bacterial pathogens associated with bovine mastitis. Infection with environmental Streptococcus spp. occurs most commonly during early lactation (Leigh, 1999) but also during the dry period (Todhunter et al., 1995). Streptococcus uberis is the most common cause of clinical mastitis in pasture-based management systems in New Zealand (Williamson et al., 1995; Pankey et al., 1996; McDougall, 1999). 
Presence of Strep. dysgalactiae IMI precalving increases the risk of clinical mastitis postcalving in heifers (Aarestrup and Jensen, 1997). Studies in multiparous cows examining the presence of previous IMI on the risk of subsequent new IMI have provided conflicting results (Hogan et al., 1988; Rainard and Poutrel, 1988; Matthews et al., 1991). Understanding the longterm effects of the presence of both minor and major pathogens on following IMI in the gland requires further work, especially in primiparous cows.

Intramammary infusion of antibiotics precalving in heifers has been shown to reduce the prevalence of IMI and to reduce the incidence of clinical mastitis postcalving (Oliver et al., 2003) by removing existing infections and reducing the risk of new infections. Barkema et al. (2006) stated that there is between-herd variation in the efficacy of precalving antibiotics, with the highest efficacy occurring in herds with a high prevalence of precalving IMI with Staph. aureus. The use of antibiotics may increase the risk of residues in milk and new infections may still be acquired before calving, because the period over which the antibiotics remain above the MIC in the glands is variable among heifers (Trinidad et al., 1990b; Oliver et al., 1992). Infusion of a teat sealant at the end of lactation has been shown to reduce the new IMI rate over the nonlactation period in multiparous cows (Woolford et al., 1998; Berry and Hillerton, 2002; Huxley et al., 2002) by acting as a physical barrier within the teat canal. Use of a teat sealant reduces the risk of antibiotic residues in milk and the sealant most likely remains in place until it is physically removed from the gland.

It was hypothesized that infusion of a teat sealant before first calving would reduce the prevalence of IMI postcalving and the incidence of clinical mastitis postpartum in heifers, and that the reduction would be greatest for Streptococcus spp.

The objectives of this study were to determine 1) the prevalence of IMI and to define bacterial species associated with IMI in pasture-fed heifers precalving; 2) if there is a relationship between presence of IMI precalving and the probability of IMI postcalving and clinical mastitis; 3) if sampling of the gland precalving would increase the risk of postcalving IMI; 4) if infusion of a teat sealant precalving would reduce the incidence of new IMI of any bacterial species; 5) if infusion of a teat sealant precalving would reduce the prevalence of postcalving IMI with any bacterial species and specifically with Strep. uberis; and 6) if infusion of a teat sealant precalving would reduce the incidence of clinical mastitis and specifically reduce the incidence of mastitis caused by Staphylococcus and Streptococcus spp.
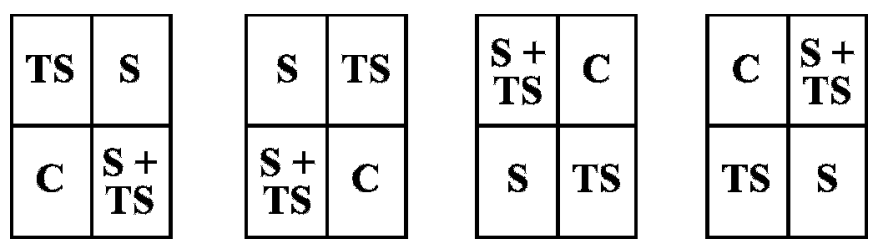

Figure 1. The 4 treatment allocations were randomly assigned to groups of 4 sequentially presented heifers within a herd. Each large box represents the 4 glands within a heifer with each smaller box representing 1 of the 4 glands, clockwise from top left; left front, right front, right rear, left rear. Treatments: $\mathrm{C}=$ glands that were not sampled or infused; TS = glands that were infused with teat sealant only; $\mathrm{S}=$ glands that were sampled with no further treatment; $\mathrm{S}+\mathrm{TS}=$ glands that were sampled and then infused with teat sealant.

\section{MATERIALS AND METHODS}

Glands $(n=1,020)$ from heifers $(n=255)$ in 5 springcalving, pasture-fed dairy herds were enrolled. Herds were selected on the basis that herd owners maintained high-quality records and agreed to be involved with the study. The herds were located in the Waikato $(\mathrm{n}=4)$ and Taranaki $(\mathrm{n}=1)$ regions of the North Island of New Zealand. Between 38 and 60 heifers were enrolled from each herd. The average herd size, total herd annual production, and bulk SCC were 357 cows, $132,644 \mathrm{~kg}$ of milk solids, and 222,731 cells/mL, respectively. In comparison, the national averages for that year were 302 cows, $98,321 \mathrm{~kg}$ of milk solids, and approximately 220,000 cells/mL, respectively (Livestock Improvement Cooperation, 2004).

A sample size of 240 animals was calculated based on the assumption that the gland-level prevalence of IMI postcalving would be $30 \%$ in the control group and $15 \%$ in the teat sealant-treated group, using a $95 \%$ confidence limit $(\alpha=0.05)$ with $80 \%$ power $(\alpha=20 \%$; Hintze, 2001).

Heifers in each herd were enrolled on one calendar day, $31 \mathrm{~d}(\mathrm{SD}=15)$ before the start of the seasonal calving period on average. The heifers calved between 6 and $89 \mathrm{~d}$ after enrollment. Treatments were assigned within heifers in a $2 \times 2$ factorial arrangement. Four different within-heifer treatment patterns were developed and these were applied randomly within sequentially presented groups of 4 heifers. The 4 patterns were designed to ensure that each treatment was applied equally to front and rear glands (Figure 1). The risk of clinical mastitis is higher in the rear than front glands (Barkema et al., 1997), which, if not accounted for, would have resulted in a potential bias if treatments were not applied equally across the front and rear glands. The glands either had a secretion collected from them only (S); a gland secretion collected followed by infusion with $2.6 \mathrm{~g}$ of bismuth subnitrate teat sealant 
(Teat Seal, Pfizer Animal Health NZ Ltd, Auckland, New Zealand; S+TS); were infused with the teat sealant only (TS); or were left as an unsampled and untreated control gland (C). Before sampling or infusion, each teat end was scrubbed with a cottonwool pledget moistened in 70\% methanol. No secretion was discarded before collection of this sample due to the small volume of secretion present in most glands. When no secretion could be collected from a gland $(n=4)$, a cottonwool pledget swab (Copan Venturi Transystem, Copan, Corona, CA) was vigorously scrubbed at the teat end and the swab cultured. The tip of the teat sealant cannula was inserted approximately $3 \mathrm{~mm}$ into the teat canal for infusion. Following sampling or infusion, $0.5 \%$ effective iodine was applied by spraying to all teats.

Within $4 \mathrm{~d}$ of calving (range 0 to $4 \mathrm{~d}$ after calving; median $=2 \mathrm{~d})$, duplicate milk samples $(\sim 20 \mathrm{~mL}$ each $)$ were collected from each gland by trained technicians for bacterial culture, following aseptic preparation of the teat end, and discard of the first 3 strippings. One heifer was sampled $32 \mathrm{~d}$ after calving and was excluded from further analysis. Herd owners collected duplicate milk samples from glands diagnosed with clinical mastitis, before treatment, from $4 \mathrm{~d}$ before to $14 \mathrm{~d}$ after calving. Clinical mastitis was defined as presence of grossly visible changes (e.g., clots or blood) in the milk composition or swelling, pain, or both in the gland.

Calving date data was retrieved from the national database (Livestock Improvement Corporation, Hamilton, New Zealand).

\section{Bacteriology}

Milk samples were processed for bacteriology within $24 \mathrm{~h}$ of collection following storage at $4^{\circ} \mathrm{C}$, except for milk samples from cases of clinical mastitis, which were frozen at $-20^{\circ} \mathrm{C}$ for up to $2 \mathrm{wk}$ before processing.

Following gentle inversion at room temperature, 10 $\mu \mathrm{L}$ of milk was streaked onto a quadrant of a $5 \%$ sheep blood agar plate containing $0.1 \%$ esculin (Fort Richard, Auckland, New Zealand), and incubated at $37^{\circ} \mathrm{C}$ for 48 $\mathrm{h}$. The genus of bacteria was provisionally determined on the basis of colony morphology, Gram stain, hemolysis pattern, catalase test, and esculin reaction. Grampositive, catalase-positive isolates were further tested using the tube coagulase test. Coagulase-positive isolates were defined as Staph. aureus and coagulase-negative isolates as CNS. Gram-positive, catalase-negative isolates were CAMP tested. Esculin-positive and CAMP-positive or CAMP-negative isolates were defined as Strep. uberis, whereas esculin-negative and CAMPnegative isolates were defined as Strep. dysgalactiae. Gram-negative rods were subcultured on MacConkey agar, had an oxidase test performed, and were cultured in triple sugar iron agar and Simmons citrate agar. Gram-negative rods that could be speciated such as Pseudomonas spp. and Escherichia coli were recorded at the genus or species level, whereas unidentified organisms were recorded as gram-negative rods. Grampositive rods that could be identified with simple procedures were identified and recorded (e.g., Corynebacterium spp.).

A milk sample was defined as contaminated if $>3$ distinct colony types were isolated. A gland was defined as infected when $\leq 3$ of each of 1 to 3 colony morphology types were isolated from both milk samples, where duplicates were taken. Major pathogens were defined as Staph. aureus, E. coli, Strep. uberis, and Strep. dysgalactiae. Multiple bacterial species were isolated from a total of 13 glands. When there was a mixed major and minor pathogen infection present ( $\mathrm{n}=10$ glands), the gland was defined as being infected with the major pathogen in subsequent analyses. In 3 quarters there were 2 major pathogens isolated (Staph. aureus and Strep. uberis, Strep. uberis and E. coli). In these quarters, Staph. aureus was the species used in further analysis if it was present ( $\mathrm{n}=1)$, otherwise Strep. uberis was the species used in further analysis $(n=2)$.

A new infection was defined as occurring when either there was no IMI precalving and an IMI was present postcalving, or where a different bacterial species was present postcalving compared with precalving.

\section{Statistical Analysis}

Dependent variables included the presence of postcalving IMI, postcalving IMI that was caused by a major pathogen, postcalving IMI with Strep. uberis, new IMI, clinical mastitis from $3 \mathrm{~d}$ before to $14 \mathrm{~d}$ after calving, and clinical mastitis from which any pathogen or only a major pathogen was isolated.

Independent (fixed) variables included precalving IMI (binomial), sampling of the gland (binomial), infusion of the teat sealant (binomial), herd, interval between infusion and calving (a continuous variable in days), number of days postcalving at sample collection (categorical), and days calved relative to the median calving date for the heifers within each herd [continuous variable (positive and negative integer)]. The median calving date of each herd and the number of days before or after that date that an individual heifer calved were calculated. Herd was included as a fixed effect due to the small number of herds $(n=5)$, and because the herds were not randomly chosen. Correlations between independent variables were tested and if the correlation coefficient was $>0.3$, then only one of the variables was included in further analysis. The variable that explained the most variation remained in the 
model. For example, day of calving relative to the median calving date of the herd was highly correlated with the number days between treatment or enrollment and calving; therefore, only days calved relative to the median calving date for each herd remained in the final models.

Bivariate associations between independent and dependent variables were examined using $\chi^{2}$ analysis and the crude odds ratios $(\mathbf{O R})$ were calculated. The MantelHaenszel procedure was used to stratify the data by herd and the adjusted relative risks (RR) were calculated. To test the hypothesis that sampling may have increased the risk of IMI postcalving or clinical mastitis, the number of glands with postcalving IMI and glands with clinical mastitis were compared between the glands that were sampled only precalving $(\mathrm{S})$ and the control glands $(\mathrm{C})$, using $\chi^{2}$ analysis. To test the hypothesis that precalving IMI specifically with CNS may increase the risk of new infection with other bacterial species, $\chi^{2}$ analysis was used.

When bivariate analyses did not identify significant relationships $(P>0.05)$ between the main effects (teat sealant, precalving IMI, or sampling precalving) and the dependent variables, further multivariate analysis was not undertaken and the bivariate results were reported (e.g., with new IMI and effect of sampling on outcomes).

Independent (predictor) variables from the bivariate and stratified analyses associated with the outcome variables (i.e., $P<0.2$ ) were manually added in a forward stepwise manner to a logistic regression model (PROC GENMOD, SAS v. 9.1; SAS Institute, 2004). Variables were included in the final models when they reached significance $(P<0.05)$. The interactions of teat sealant by sampling, teat sealant by precalving IMI status, and teat sealant and herd were tested within each model and were removed, because they were not significant (i.e., $P>0.05$ ).

The final models with postcalving IMI (any pathogen, major pathogen, and Strep. uberis) as the dependent variable included herd, teat sealant, precalving IMI status, and days from calving to sampling as fixed effects (models 1 to 3 ). The final models with clinical mastitis (clinical mastitis culturing any pathogen and clinical mastitis culturing a major pathogen) as the dependent variable included herd, teat sealant, precalving IMI status, and days from calving relative to the median calving date of the group (models 4 and 5). When precalving IMI was included in the models, only half the glands were included in the analysis due to the $2 \times 2$ design of the experiment. Therefore, the same logistic regression models were tested without precalving IMI status included, which doubled the number of glands in the analysis (models 6 to 10). Clinical mastitis (including those cases not culturing a pathogen) was only analyzed at the univariate level, because the multivariate model was unstable.

The OR were converted to adjusted $R R$ using the technique of Beaudeau and Fourichon (1998), because the OR may have led to an overestimation of the size of the main effects (Dohoo et al., 2003). Relative risks with 95\% confidence intervals (CI) and number of glands (n) reported in the text were calculated from the final multivariate models.

Seventeen individual glands from 17 heifers were diagnosed with clinical mastitis and were milk sampled and then treated by intramammary infusion of antibiotics before the routine postcalving samples had been collected. All glands from these animals were subsequently sampled at the routine visit within $4 \mathrm{~d}$ postcalving; 5 of the samples from these glands from the nonclinical quarters cultured bacteria ( 4 were CNS and 1 was Strep. uberis). The bacteriology result from the sample collected from the gland with clinical mastitis before treatment was used as the postcalving bacteriology result for that gland. Due to the risk that antibiotic treatment of one gland may have resulted in translocation of antibiotic to the other glands within the heifers, the bacteriology results from the remaining glands' samples, collected at the routine visit within $4 \mathrm{~d}$ of calving, were discarded and the gland defined as having a missing sample at the postcalving sampling. Hence, the results from these 17 heifers $(n=48$ glands $)$ were excluded from the postcalving IMI data analysis. Of these 48 glands, 11 were control glands, 14 were treated with teat sealant precalving, 11 were sampled precalving, and 12 were sampled and treated. Of these 48 glands, 37 were from one herd.

Because glands within a cow are not biologically independent, the degree of correlation of results between glands was examined (Barkema et al., 1997). When the correlation is high, failure to account for the correlated nature of the data may lead to underestimation of the variance (Schukken et al., 2003), overestimation of the significance of results and hence the drawing of incorrect inferences. Dohoo et al. (2003) state that ignoring clustering can lead to deficiencies other than variance inflation and even when no correlation or dependence is seen, cluster-adjusted methods should be used where the data are not independent. The intraclass correlation (ICC), which is the proportion of variance of gland within cow, was $<0.18$ for all variables, calculated using 1-way ANOVA for each dependent variable (Dohoo et al., 2003). An ICC of $<0.2$ suggests a low degree of correlation and hence, that clustering is of limited importance. The variance inflation factor was calculated by accounting for the numbers of glands within cow and was also found to be small $(<20 \%$; Dohoo et al., 
Table 1. Number and percentage of glands with IMI $31 \mathrm{~d}$ (on average) before the start of a seasonal calving period

\begin{tabular}{|c|c|c|c|c|c|c|}
\hline \multirow[b]{3}{*}{ Bacterial species cultured } & \multicolumn{4}{|c|}{ Treatment group $^{1}$} & & \\
\hline & \multicolumn{2}{|c|}{$\mathrm{S}$} & \multicolumn{2}{|c|}{$\mathrm{S}+\mathrm{TS}$} & \multicolumn{2}{|c|}{ Total } \\
\hline & $\mathrm{n}$ & $\%$ & $\mathrm{n}$ & $\%$ & $\mathrm{n}$ & $\%$ \\
\hline No growth & 185 & 72.8 & 202 & 81.1 & 387 & 76.9 \\
\hline $\mathrm{CNS}$ & 34 & 13.4 & 26 & 10.4 & 60 & 11.9 \\
\hline Corynebacterium spp. & 2 & 0.8 & 1 & 0.4 & 3 & 0.6 \\
\hline Staphylococcus aureus & 4 & 1.6 & 0 & 0.0 & 4 & 0.8 \\
\hline Streptococcus uberis & 9 & 3.5 & 2 & 0.8 & 11 & 2.2 \\
\hline Contaminated sample ${ }^{2}$ & 20 & 7.9 & 18 & 7.2 & 38 & 7.6 \\
\hline Total precalving IMI & 49 & 19.3 & 29 & 11.6 & 78 & 15.5 \\
\hline Total glands & 254 & 100 & 249 & 100 & 503 & 100 \\
\hline
\end{tabular}

\footnotetext{
${ }^{1}$ Treatments: $\mathrm{S}=$ glands that were sampled with no further treatment; $\mathrm{S}+\mathrm{TS}=$ glands that were sampled and then infused with teat sealant.

${ }^{2}$ Defined as $>3$ distinct colony morphology types present.
}

2003). To further examine the potential effects of nonindependence of gland within heifer, a GLM (GLIMMIX; SAS v. 9.1) was developed using the variables significant in the logistic regression models, with and without adjusting for clustering by use of a repeated measures statement for heifer and using a compound symmetry adjustment to account for correlation of gland within heifer. Compound symmetry adjusts for correlation by assuming that the correlation between glands within heifer is the same for every heifer. The $-2 \log$ likelihood (model deviance) and error terms were compared for the 2 types of model for each of the final models; in each case the model deviance was not significantly different between the 2 models $(P>0.1)$ and the standard errors were no larger in the models that adjusted for correlation. Therefore, because the correlation coefficients were small and adjustment for correlation did not improve or alter the models, the outcomes from the logistic models were reported.

Statistical significance was taken for test $P \leq 0.05$, and CI reported are for a $95 \%$ range of values.

Data were recorded in a Microsoft Access database, and statistical analysis was carried out using SAS version 9.1 (SAS Institute, 2004).

\section{RESULTS}

One heifer was culled for being nonpregnant before calving start date and a further heifer removed from analysis because the postcalving samples were not collected within $4 \mathrm{~d}$ of calving. None of the teat-end swabs (those glands with no secretion collected; $\mathrm{n}=4$ ) cultured any bacteria; these were recorded as missed samples and dropped from further analysis. Six glands were nonfunctional postcalving and therefore excluded from the analysis.

\section{Objective 1}

The gland prevalence of IMI precalving was $15.5 \%$ (Table 1) and did not differ between herds $(P=0.69)$. The most common isolates were CNS (11.9\% of glands) and Strep. uberis (2.2\% of glands; Table 1).

\section{Objective 2}

The postcalving IMI mean gland prevalence for the control group was $12.3 \%$, which differed between herds $(P=0.001)$. Coagulase-negative staphylococci and Strep. uberis were the most common isolates (4.9 and $4.2 \%$ respectively; Table 2 ).

Presence of a precalving IMI, relative to no precalving IMI, increased the risk of postcalving IMI with any bacterial species $[22 / 73(30.1 \%)$ vs. $25 / 362(6.9 \%)$; $R R=$ $3.55,95 \% \mathrm{CI}=2.0-5.7, P<0.001]$, with major bacterial pathogens $[11 / 73(15.1 \%)$ vs. $14 / 362(3.9 \%) ; R R=2.85$, $95 \% \mathrm{CI}=1.35-6.16, P=0.003]$, and with Strep. uberis $[6 / 73(8.2 \%)$ vs. $8 / 362(2.2 \%) ; \mathrm{RR}=3.23,95 \% \mathrm{CI}=$ 0.95-7.62, $P=0.06]$.

Precalving IMI with CNS increased the risk of postcalving IMI with CNS, Strep. uberis, and Staph. aureus (Table 3). The prevalence of postcalving IMI declined with increasing number of days from calving to sampling postcalving (Figure 2).

The cumulative incidences of clinical mastitis for the control groups were $21.4 \%$ of heifers and $6.7 \%$ of glands. The incidence differed across herds $(P<0.001)$. More rear glands than fore glands were diagnosed with clinical mastitis [37/470 (7.9\%) vs. $18 / 491(3.7 \%) ; P<0.01]$.

Precalving IMI was not associated with risk of clinical mastitis overall $(P=0.15)$. However, presence of a precalving IMI relative to no precalving IMI increased the risk of clinical mastitis from which any bacterial species was isolated [10/76 (13.2\%) vs. 9/389 (2.3\%); $\mathrm{RR}=4.78$, 
PARKER ET AL.

Table 2. Number and percentage of glands with IMI within $4 \mathrm{~d}$ after calving

\begin{tabular}{|c|c|c|c|c|c|c|c|c|c|c|}
\hline \multirow[b]{3}{*}{ Bacterial species cultured } & \multicolumn{8}{|c|}{ Treatment $^{1}$} & & \\
\hline & \multicolumn{2}{|c|}{$\mathrm{C}$} & \multicolumn{2}{|c|}{$\mathrm{TS}$} & \multicolumn{2}{|c|}{$\mathrm{S}$} & \multicolumn{2}{|c|}{$\mathrm{S}+\mathrm{TS}$} & \multicolumn{2}{|c|}{ Total } \\
\hline & $\mathrm{n}$ & $\%$ & $\mathrm{n}$ & $\%$ & $\mathrm{n}$ & $\%$ & $\mathrm{n}$ & $\%$ & $\mathrm{n}$ & $\%$ \\
\hline No growth & 221 & 87.7 & 224 & 88.2 & 217 & 85.8 & 224 & 90.7 & 886 & 88.1 \\
\hline $\mathrm{CNS}$ & 13 & 5.2 & 10 & 3.9 & 15 & 5.9 & 11 & 4.5 & 49 & 4.9 \\
\hline Staphylococcus aureus & 4 & 1.6 & 5 & 2.0 & 4 & 1.6 & 4 & 1.6 & 17 & 1.7 \\
\hline Streptococcus uberis & 14 & 5.6 & 11 & 4.3 & 14 & 5.5 & 3 & 1.2 & 42 & 4.2 \\
\hline Streptococcus dysgalactiae & 0 & 0 & 1 & 0.4 & 1 & 0.4 & 0 & 0 & 2 & 0.2 \\
\hline Escherichia coli & 0 & 0 & 2 & 0.8 & 1 & 0.4 & 1 & 0.4 & 4 & 0.4 \\
\hline Pseudomonas spp. & 0 & 0 & 0 & 0 & 0 & 0 & 1 & 0.4 & 1 & 0.1 \\
\hline Yeast & 0 & 0 & 0 & 0 & 1 & 0.4 & 0 & 0 & 1 & 0.1 \\
\hline Contaminated sample ${ }^{2}$ & 0 & 0 & 1 & 0.4 & 0 & 0 & 3 & 1.2 & 4 & 0.4 \\
\hline Total IMI & 31 & 12.3 & 29 & 11.4 & 35 & 13.8 & 20 & 8.1 & 115 & 11.4 \\
\hline Total glands & 252 & 100 & 254 & 100 & 253 & 100 & 247 & 100 & 1,006 & 100 \\
\hline
\end{tabular}

\footnotetext{
${ }^{1}$ Treatments: $\mathrm{C}=$ glands that were not sampled or infused; $\mathrm{TS}=$ glands that were infused with teat sealant only; $\mathrm{S}=$ glands that were sampled with no further treatment; $\mathrm{S}+\mathrm{TS}$ = glands that were sampled and then infused with teat sealant.

${ }^{2}$ Defined as $>3$ distinct colony morphology types present.
}

$95 \% \mathrm{CI}=1.85-11.1, P=0.001]$, and with clinical mastitis from which a major pathogen was isolated $[8 / 76$ $(10.5 \%)$ vs. $9 / 389(2.3 \%) ; \mathrm{RR}=3.76,95 \% \mathrm{CI}=1.41-9.37$, $P<0.001]$.

\section{Objective 3}

Sampling precalving did not increase the risk of postcalving IMI $(\mathrm{RR}=1.05,95 \% \mathrm{CI}=0.75-1.48, P=0.77$; Table 2$)$ or the risk of clinical mastitis postcalving $(\mathrm{RR}=$ $1.05,95 \% \mathrm{CI}=0.63-1.75, P=0.69$; Table 4 ) relative to not sampling.

\section{Objective 4}

Forty of 440 glands (9.1\%) acquired new infections between pre- and postcalving sampling. Of these, 13 were Strep. uberis, 16 were CNS, 6 were Staph. aureus, and 5 were other species. Sixteen glands $(3.6 \%)$ had the same bacterial species isolated pre- and postcalving, and 54 glands (12.3\%) apparently underwent spontaneous cure. Neither the presence of IMI precalving [27/
$380(7.1 \%)$ vs. $9 / 76(11.8 \%) ; \mathrm{RR}=1.67,95 \% \mathrm{CI}=$ $0.82-3.4, P=0.17]$, nor the use of a teat sealant (24/ $234(10.3 \%)$ vs. $16 / 236(6.8 \%) ; \mathrm{RR}=0.69,95 \% \mathrm{CI}=$ $0.38-1.3, P=0.23$ ] significantly altered the risk of new infection.

\section{Objective 5}

Treatment with a teat sealant precalving relative to no treatment with teat sealant tended to decrease the risk of postcalving IMI with any bacterial species [66/ $483(13.7 \%)$ vs. $45 / 471(9.6 \%) ; \mathrm{RR}=0.69,95 \% \mathrm{CI}=$ $0.48-1.01, P=0.05$; model 1 , Table 5], and with major bacterial pathogens $[38 / 483(7.9 \%)$ vs. $27 / 471(5.7 \%)$; $\mathrm{RR}=0.71,95 \% \mathrm{CI}=0.43-1.19, P=0.2$; model 3 , Table 5]. There was a significant decrease in the risk of postcalving IMI with Strep. uberis following the use of a teat sealant compared with no teat sealant $[29 / 483$ $(6.0 \%)$ vs. $13 / 471(2.8 \%) ; \mathrm{RR}=0.44,95 \% \mathrm{CI}=0.23-0.86$, $P=0.02$; model 2 , Table 5]. The RR of postcalving IMI when precalving IMI status was adjusted for were 0.59 , 0.45 , and 0.16 for postcalving IMI with any bacterial

Table 3. Relative risks (RR) with 95\% confidence intervals (CI) and probability values, calculated using $\chi^{2}$ analysis, for the outcome postcalving IMI, in the presence or absence of a precalving IMI with CNS

\begin{tabular}{lccccccc}
\hline & \multicolumn{2}{c}{ Precalving IMI } & & & \multicolumn{2}{c}{$95 \%$ CI } & \\
\cline { 2 - 3 } Postcalving IMI & CNS & No growth & & RR & Lower & Upper & $P$ \\
\hline No growth & 39 & 337 & & 0.76 & 0.6 & 0.9 & $<0.001$ \\
CNS & 9 & 10 & & 5.91 & 2.5 & 13.9 & $<0.001$ \\
Staphylococcus aureus & 3 & 3 & & 6.56 & 1.4 & 31.7 & 0.008 \\
Streptococcus uberis & 4 & 8 & & 3.28 & 1.0 & 10.5 & 0.04 \\
Other $^{1}$ & 0 & 4 & & & & & \\
Total & 55 & 362 & & & & & \\
\hline
\end{tabular}

${ }^{1}$ Other = Streptococcus dysgalactiae, Escherichia coli, Pseudomonas spp., and yeast. 


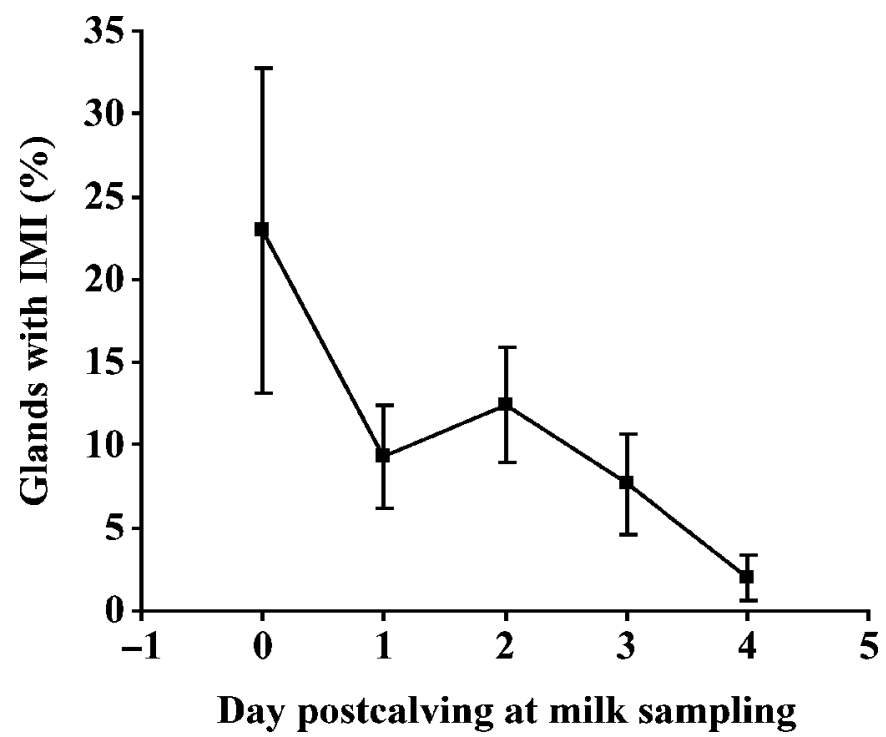

Figure 2. Mean $( \pm$ SEM) prevalence as a percentage of glands with IMI by day postcalving at milk sampling.

species, postcalving IMI with a major pathogen, and postcalving IMI with Strep. uberis, respectively (models 6,8 , and 7, Table 5).

\section{Objective 6}

Teat sealant tended to decrease the risk of all clinical mastitis cases $[34 / 501(6.8 \%)$ vs. $21 / 501(4.2 \%) ; \mathrm{RR}=$ $0.63,95 \% \mathrm{CI}=0.36-1.1, P=0.07]$. Teat sealant did decrease the risk of clinical mastitis from which any bacterial pathogen was isolated [30/501 (6.0\%) vs. 10/ $501(2.0 \%) ; \mathrm{RR}=0.36,95 \% \mathrm{CI}=0.18-0.72, P=0.004]$, and clinical mastitis from which a major pathogen was isolated [24/501 (4.8\%) vs. 7/501 (1.4\%); $\mathrm{RR}=0.33,95 \%$ $\mathrm{CI}=0.15-0.73, P=0.01$; models 4 and 5 , Table 5] when precalving IMI status was not adjusted for. The RR of clinical mastitis when precalving IMI status was adjusted for were 0.32 and 0.36 for clinical mastitis that isolated any bacterial species, and clinical mastitis that isolated a major pathogen, respectively (models 9 and 10, Table 5). Across all groups, $69.1 \%$ of glands with clinical mastitis were bacteriologically positive (Table 4). The number of clinical mastitis cases that had no bacterial pathogen cultured from them was higher in the glands treated with teat sealant [4/34 (11.8\%) vs. $10 / 21(47.6 \%) ; \mathrm{RR}=4.2,95 \% \mathrm{CI}=1.5-11.6, P=0.003]$. The risk of clinical mastitis tended to decline for heifers calving later relative to the start of the calving period for the herd $(P<0.07)$ for all models with a clinical mastitis outcome (Figure 3 ).

\section{DISCUSSION}

\section{Objective 1}

This is the first time since 1970 (Munch-Peterson, 1970) that the prevalence of IMI has been estimated in precalving heifers in a pasture-based grazing system. The gland level prevalence of precalving IMI in the current study was $15.5 \%$. This prevalence is lower than that described in more intensive management systems, in which between 50 and $97 \%$ of glands have been reported as infected (Trinidad et al., 1990a; Oliver et al., 1992, 1997). The most prevalent precalving isolates in the current study were CNS (11.9\%), in agreement with previous studies (Oliver and Mitchell, 1983; Fox et al., 1995; Aarestrup and Jensen, 1997).

Table 4. Number and percentage of bacterial species from glands diagnosed with clinical mastitis from 3 $\mathrm{d}$ before to $14 \mathrm{~d}$ after calving following treatment approximately $31 \mathrm{~d}$ before the start of a seasonal calving program

\begin{tabular}{|c|c|c|c|c|c|c|c|c|c|c|}
\hline \multirow[b]{3}{*}{ Bacterial species cultured } & \multicolumn{8}{|c|}{ Treatment $^{1}$} & & \\
\hline & \multicolumn{2}{|c|}{$\mathrm{C}$} & \multicolumn{2}{|c|}{$\mathrm{TS}$} & \multicolumn{2}{|c|}{$\mathrm{S}$} & \multicolumn{2}{|c|}{$\mathrm{S}+\mathrm{TS}$} & \multicolumn{2}{|c|}{ Total } \\
\hline & $\mathrm{n}$ & $\%$ & $\mathrm{n}$ & $\%$ & $\mathrm{n}$ & $\%$ & $\mathrm{n}$ & $\%$ & $\mathrm{n}$ & $\%$ \\
\hline No growth & 3 & 17.6 & 3 & 33.3 & 1 & 5.9 & 7 & 58.3 & 14 & 25.5 \\
\hline CNS & 4 & 23.5 & 1 & 11.1 & 2 & 11.8 & 0 & 0 & 7 & 12.7 \\
\hline Staphylococcus aureus & 1 & 5.9 & 0 & 0.0 & 1 & 5.9 & 1 & 8.3 & 3 & 5.5 \\
\hline Streptococcus uberis & 9 & 52.9 & 3 & 33.3 & 13 & 76.5 & 2 & 16.7 & 27 & 49.1 \\
\hline Escherichia coli & 0 & 0 & 0 & 0 & 0 & 0 & 1 & 8.3 & 1 & 1.8 \\
\hline Fungi & 0 & 0 & 2 & 22.2 & 0 & 0 & 0 & 0 & 2 & 3.6 \\
\hline Contaminated sample ${ }^{2}$ & 0 & 0 & 0 & 0.0 & 0 & 0 & 1 & 8.3 & 1 & 1.8 \\
\hline Total glands pathogen positive & 14 & 82.4 & 4 & 44.4 & 16 & 94.1 & 4 & 33.3 & 38 & 69.1 \\
\hline Total clinical mastitis of all glands & 17 & 6.7 & 9 & 3.5 & 17 & 6.8 & 12 & 4.9 & 55 & 5.5 \\
\hline Total glands & 252 & & 254 & & 249 & & 247 & & 1,002 & \\
\hline
\end{tabular}

\footnotetext{
${ }^{1}$ Treatments: $\mathrm{C}=$ glands that were not sampled or infused; $\mathrm{TS}=$ glands that were infused with teat sealant only; $\mathrm{S}=$ glands that were sampled with no further treatment; $\mathrm{S}+\mathrm{TS}=$ glands that were sampled and then infused with teat sealant.

${ }^{2}$ Defined as $>3$ distinct colony morphology types present.
} 
Table 5. Adjusted relative risks (RR) and 95\% confidence intervals (95\% CI) with probability values (P) calculated from the final logistic regression models for the dependent variables ${ }^{1}$

\begin{tabular}{|c|c|c|c|c|c|c|c|c|c|c|}
\hline \multirow[b]{3}{*}{ Outcome } & \multicolumn{5}{|c|}{ Precalving IMI not adjusted for } & \multicolumn{5}{|c|}{ Precalving IMI adjusted for } \\
\hline & \multirow[b]{2}{*}{ Model } & \multirow[b]{2}{*}{$\mathrm{RR}$} & \multicolumn{2}{|c|}{$95 \% \mathrm{CI}$} & \multirow[b]{2}{*}{$P$} & \multirow[b]{2}{*}{ Model } & \multirow[b]{2}{*}{$\mathrm{RR}$} & \multicolumn{2}{|c|}{$95 \% \mathrm{CI}$} & \multirow[b]{2}{*}{$P$} \\
\hline & & & Lower & Upper & & & & Lower & Upper & \\
\hline Postbactall & 1 & 0.69 & 0.48 & 1.01 & 0.05 & 6 & 0.59 & 0.36 & 1.04 & 0.07 \\
\hline Postsu & 2 & 0.44 & 0.23 & 0.86 & 0.02 & 7 & 0.16 & 0.04 & 0.74 & 0.01 \\
\hline Postbactmjr & 3 & 0.71 & 0.43 & 1.19 & 0.20 & 8 & 0.45 & 0.20 & 1.07 & 0.06 \\
\hline Clinbactall & 4 & 0.36 & 0.18 & 0.72 & 0.00 & 9 & 0.32 & 0.10 & 0.96 & 0.04 \\
\hline Clinbactmjr & 5 & 0.33 & 0.15 & 0.73 & 0.01 & 10 & 0.36 & 0.11 & 1.10 & 0.07 \\
\hline
\end{tabular}

${ }^{1}$ Variables: postcalving IMI (Postbactall), postcalving IMI with Streptococcus uberis (Postsu), postcalving IMI with a major pathogen (Postbactmjr), clinical mastitis culturing a pathogen (Clinbactall), clinical mastitis culturing a major pathogen (Clinbactmjr) following infusion with a teat sealant approximately $31 \mathrm{~d}$ before the planned start of calving of the herd. Models 1 to $5(\mathrm{n}=503)$ do not include precalving bacteriology status as a variable in the model, whereas models 6 to 10 do include precalving bacteriology status $(\mathrm{n}=$ 1,006). Herd is included in all models as a fixed effect. Days from calving to sampling were included as a categorical variable in all postcalving IMI models (models 1 to 3 and 6 to 8 ) and days calved relative to the group median calving date in the clinical mastitis models (models 4, 5, 9, and 10).

The prevalence of Strep. uberis $(2.2 \%)$ was numerically similar to, but proportionally higher than, that reported in previous studies (Trinidad et al., 1990a; Fox et al., 1995). The prevalence of Staph. aureus was lower in the current study $(0.8 \%)$ compared with other studies, in which the prevalence was from 9 to $15 \%$ (Trinidad et al., 1990a; Fox et al., 1995). Overall, the prevalence of major pathogens was lower in the current study (3\%) than that reported in previous studies (8 to 10\%; Oliver et al., 1992; Fox et al., 1995). This suggests that the prevalence of precalving IMI in heifers reared and calved under pasture-based management systems maybe lower than in heifers reared and then calved under more intensive conditions.

Regional and seasonal variations in prevalence and relative frequency of IMI pathogens have been reported

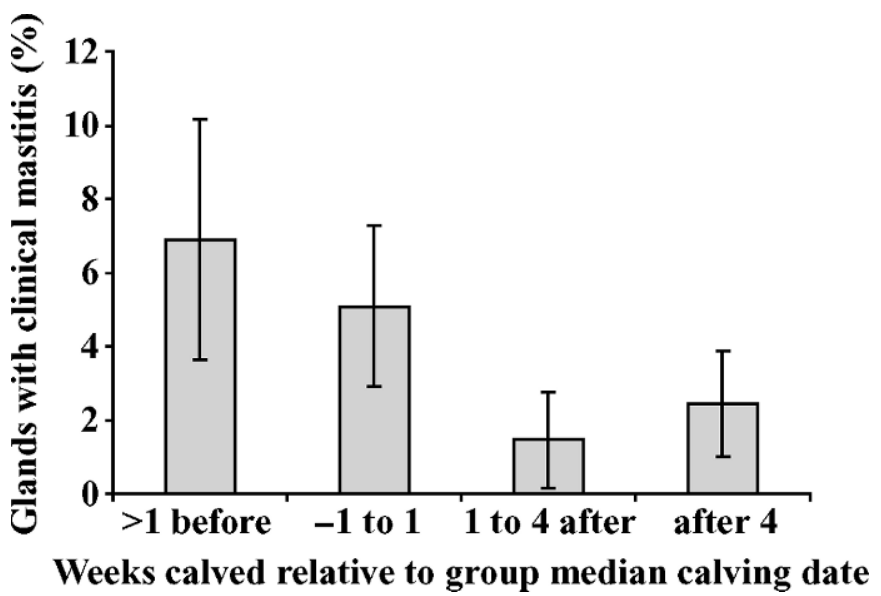

Figure 3. The mean cumulative incidence of clinical mastitis $( \pm$ SEM) within herd from which any pathogen was isolated by week of calving relative to the median calving week for heifers within a herd. previously (Fox et al., 1995). This may be related to regional variation in managerial approaches, genetics of the animals, or climatic conditions and hence bacterial survival (Fox et al., 1995). Specific regional factors such as presence of the horn fly (which has been shown to transmit Staph. aureus) might account for some regional variation (Fox et al., 1995; Owens et al., 2002). Higher proportions of cereals and lower proportions of ryegrass in the diet are associated with higher bulk tank SCC (Barnouin et al., 1995), suggesting a potential association between diet and IMI. Increasing production is also associated with increased risk of clinical mastitis (Chassagne et al., 1998; Waage et al., 1998). Thus, the lower prevalence of IMI pre- and postcalving, the lower incidence rate of clinical mastitis, and the different distribution of pathogens observed in the current study compared with previous studies in different production systems, may be related to a number of the above mentioned factors. The major differences among the production systems are that heifers in New Zealand calve predominantly in spring, that the majority of the diet is pasture rather than concentrate feeds or silage, that the cattle are managed on pasture and not housed, and that the production levels are generally lower than in the more intensive production systems.

\section{Objective 2}

The postcalving IMI gland-level prevalence of $12.3 \%$ in the control glands was lower than that reported in studies carried out in the United States (between 31 and 75\%; Fox et al., 1995; Nickerson et al., 1995; Oliver et al., 2003). Clinical mastitis was diagnosed in $21.9 \%$ of heifers in the first $2 \mathrm{wk}$ after calving across all treatment groups in the current study, which was similar to the $8.1 \%$ diagnosed in the first $5 \mathrm{~d}$ after calving in 
a previous New Zealand study, when the differing period is accounted for (Pankey et al., 1996). Difference in climate, season, and region may lead to potential difference in incidence between studies.

In the present study, IMI precalving was associated with an increased risk of IMI postcalving, in agreement with previous findings in heifers specifically for Strep. dysgalactiae (Aarestrup and Jensen, 1997) and in lactating cows (Hogan et al., 1988). However, studies in multiparous cows examining the effect of the presence of CNS IMI on the risk of subsequent new IMI have yielded conflicting results. In the current study, precalving IMI with CNS increased the risk of postcalving IMI with CNS, Strep. uberis, and Staph. aureus, despite the small number of IMI with major pathogens. One limitation of the current study is that no speciation was performed on the CNS isolates; hence, whether the postcalving isolate is the same infection or a new infection of CNS is unclear. The current study provides contradictory findings to studies in multiparous cows, and suggests that glands previously infected with minor pathogens, in particular CNS, are more resistant to subsequent, naturally acquired infections than are uninfected glands (Edwards and Jones, 1966; Rainard and Poutrel, 1988; Matthews et al., 1991). Glands infected with CNS showed a reduced rate of IMI following experimental challenge with Staph. aureus compared with bacteriologically negative glands (Pankey et al., 1985). A recent in vitro study found that Staphylococcus chromogenes obtained from the teat apex of heifers consistently inhibited all growth of Staph. aureus, Strep. dysgalactiae, and Strep. uberis strains (De Vliegher et al., 2004). However, in vitro and experimental challenge studies may not be comparable to natural exposure. Some studies have demonstrated that glands infected with Corynebacterium bovis are less likely to become infected with major pathogens than uninfected glands (Black et al., 1972; Rainard and Poutrel, 1988; Lam et al., 1997). Other studies have however demonstrated that glands with $C$. bovis are significantly more likely to become infected with environmental Streptococcus spp. (Hogan et al., 1988) and Streptococcus agalactiae (Pankey et al., 1985). Green et al. (2002) attempted to investigate the conflicting evidence supporting the protective effects of Corynebacterium spp. and found that glands from which Corynebacterium spp. were isolated at drying off were at an increased risk of clinical mastitis, whereas the presence of Corynebacterium spp. in the late dry and postcalving periods were associated with a reduction in the risk of IMI and clinical mastitis during lactation. A possible explanation for this is that the protective effects of Corynebacterium spp. (identified in many studies) are masked because glands with an IMI may be innately susceptible to repeat infection, irrespective of the protective effect of the Corynebacterium spp. IMI. Understanding the long-term effects of the presence of minor pathogens in the gland requires further work, especially in primiparous cows. Based on the results from this study, strategies intended to reduce postcalving IMI and clinical mastitis in heifers should aim to cure existing IMI precalving, as well as minimize new infections during the high-risk pericalving period.

\section{Objective 3}

Sampling glands precalving did not increase the risk of subclinical or clinical mastitis postcalving in agreement with a study in multiparous cows (Green et al., 2002). This is despite the fact that removal of the keratin teat plug in the process of sampling might increase the risk of bacteria entering the teat canal and establishing an IMI. Removing keratin from the teat canal premilking reduces teat plug formation (Capuco et al., 1992) and consequently increases the risk of IMI (Dingwell et al., 2004). It could be argued that if a teat plug were present, if sampling removed that plug, and if the teat plug were protective, then sampling should have increased risk of new IMI. However, the presence or absence of a teat plug was not assessed either preor postcalving in the current study. Hence, it is not clear whether a teat plug was present precalving, whether precalving sampling was associated with removal of any teat plug that was present, or whether a teat plug reformed after sampling and before calving. Additionally, the presence and role of a teat plug has not been defined in heifers and requires this further study.

\section{Objectives 4, 5, and 6}

Insertion of teat sealant before calving reduced the risk of any IMI or an IMI with Strep. uberis postcalving by between 41 and $84 \%$ and reduced the risk of a gland developing clinical mastitis caused by any bacteria within 2 wk of calving by between 68 and $64 \%$. There was no interaction between infusion of the teat sealant and precalving IMI status. However, the estimated size of the effect of teat sealant increased following inclusion of precalving IMI in the models. This indicates that presence of IMI may be a potential confounder to the effect of teat sealant and therefore should be included in the models. However, the CI for the models with and without the precalving IMI in the model overlapped, indicating that no differences in the inferences can be drawn.

Teat sealants, when infused at the end of lactation in mature cows, reduce the incidence of new IMI over the nonlactation period (Woolford et al., 1998; Berry 
and Hillerton, 2002; Huxley et al., 2002). The teat sealant is likely to remain effective until it is physically stripped or sucked from the gland (Woolford et al., 1998; Berry and Hillerton, 2002; Huxley et al., 2002). Although the teat sealant numerically reduced the number of glands acquiring new infections precalving, this was not statistically significant. However, the small number of new infections precluded definitive rejection of the null hypothesis. Power analysis suggested that 474 glands per treatment group would be required to demonstrate a significant difference assuming a 50\% decrease in new infection rate when the new infection rate was $10 \%$ in the control glands, with $\alpha<0.05$, and with a power of $80 \%(\alpha=0.2$; Hintze, 2001). Additionally, a new IMI due to the same species would not have been detected in the current study because no genotyping of bacterial isolates was undertaken. Thus, the use of genotypic techniques might also have improved the power of the study to detect new IMI.

There was a lower prevalence of precalving IMI in the glands infused with teat sealant precalving than those left untreated. The reasons for this are not clear. There was also a lower prevalence of IMI postcalving in these same glands, which may lead to the assumption that the apparent effect of teat sealant reducing the prevalence of postcalving IMI was due only to the difference in precalving IMI status. However, the multivariate statistical model included the precalving IMI status, and the effect of teat seal on postcalving IMI prevalence was found to be independent of precalving IMI status. This is interpreted as meaning that although there was a difference in precalving IMI prevalence, the teat sealant still significantly reduced the prevalence postcalving.

The higher occurrence of clinical mastitis cases from which no bacteria were isolated in the glands treated with the teat sealant has not been reported previously. We hypothesize that the increased proportion of "no growth samples" may have been associated with an increased proportion of false-positive diagnoses of clinical mastitis by the herd owners, who incorrectly assumed that the presence of flecks of teat sealant in the milk was mastitis. Berry and Hillerton (2002) reported flecks present in the milk for up to 3 wk postcalving in some cows following treatment with teat sealant at the end of the lactating period.

\section{Other Findings}

Administration of the teat sealant into the teat canals of heifers up to $10 \mathrm{wk}$ precalving was not difficult. Herd owners had been encouraged to familiarize the heifers with the milking parlor before the date of infusion. All infusions were undertaken within the parlor. The heifers were not routinely restrained except when an animal started kicking, in which case the tail was held above horizontal ("tail jacked") while infusion or sampling occurred. There were a small number of quarters $(<5 \%)$ that had small teat orifices and were difficult to infuse. The effect of time precalving at which infusion occurred on the difficulty of infusion was not recorded.

The decline in percentage of glands diagnosed with clinical mastitis in heifers calving after the median calving date of the herd was an unexpected finding. In the seasonal calving system, 50 to $70 \%$ of heifers calve in the first $3 \mathrm{wk}$ of the calving period. It appears from this study that the peak of the heifer calving period is associated with a higher incidence of clinical mastitis. This may be a chance finding and related to increased exposure to mastitis pathogens due to wet and cold conditions over this period, with resultant increased fecal contamination on the udder and an increased risk of IMI (Schreiner and Ruegg, 2003). Alternatively, it could be related to changes in farm management practice resulting in increased exposure to mastitis risk factors or to changes in sensitivity of clinical mastitis diagnosis across the calving period. Management changes such as calves being left with their dams for longer periods or heifers left on fecally contaminated pasture for longer may have occurred during this period.

Day of calving relative to the median calving date of the herd was highly correlated with the number of days between treatment and calving. That is, as the interval between precalving treatment and calving increased, the incidence of clinical mastitis decreased, which may lead to the assumption that the earlier a quarter is infused with teat sealant precalving, the lower the risk of clinical mastitis. However, this is confounded by calving spread and seasonal effects. A further study examining the effect of season and interval between infusion of teat sealant and calving on risk of mastitis needs to be undertaken to clarify this effect.

In the current study, the calculated ICC between glands was only moderate (i.e., ICC $<0.2$ ) and the use of models that accounted for the clustering of gland within cow did not result in changes in estimates of variance or to inferences compared with simpler models that did not account for this clustering. The risk of Staph. aureus being isolated from a gland from a lactating cow is increased by the presence of Staph. aureus in another gland within the same cow, illustrating that glands are not independent within a cow (Zadoks et al., 2001). This discrepancy between studies may be related to the fact that the most common major pathogen isolated in this study was Strep. uberis, which may be defined as an environmental pathogen (Todhunter et al., 1995). Thus, although evidence does exist of poten- 
tial cow-to-cow transmission (Zadoks et al., 2003), it is likely that the major source of this pathogen is external to the cow (Douglas et al., 2000; McDougall et al., 2004); hence, presence of an infection in one gland may not increase risk of infection in another within the same animal. Additionally, heifers in the current study were sampled before and within $4 \mathrm{~d}$ of calving, so that exposure to the milking process and hence the risk of cross infection within the heifer via the milking claw may be relatively low.

\section{CONCLUSIONS}

Precalving IMI is a significant risk factor for IMI postcalving and clinical mastitis in early lactation. Sampling of the glands precalving did not increase the risk of IMI postcalving. Insertion of a teat sealant approximately $30 \mathrm{~d}$ before calving decreased the risk of postcalving IMI with Strep. uberis and clinical mastitis in the first $14 \mathrm{~d}$ of lactation. The findings of the current study present farmers with an alternative and practical treatment of reducing the prevalence of IMI and clinical mastitis in heifers postcalving.

\section{ACKNOWLEDGMENTS}

The authors would like to thank the herd owners and their staff and Helena Habgood for her technical support. The Animal Health Centre, Morrinsville, Eltham District Veterinary Services, Eltham, and Pfizer Animal Health provided funding for this study.

\section{REFERENCES}

Aarestrup, F. M., and N. E. Jensen. 1997. Prevalence and duration of intramammary infection in Danish heifers during the peripartum period. J. Dairy Sci. 80:307-312.

Barkema, H. W., Y. H. Schukken, T. Lam, M. L. Beiboer, H. Wilmink, G. Benedictus, and A. Brand. 1998. Incidence of clinical mastitis in dairy herds grouped in three categories by bulk milk somatic cell counts. J. Dairy Sci. 81:411-419.

Barkema, H. W., Y. H. Schukken, T. Lam, D. T. Galligan, M. L. Beiboer, and A. Brand. 1997. Estimation of interdependence among quarters of the bovine udder with subclinical mastitis and implications for analysis. J. Dairy Sci. 80:1592-1599.

Barkema, H. W., Y. H. Schukken, and R. N. Zadoks. 2006. Invited review: The role of cow, pathogen and treatment regimen in the therapeutic success of bovine Staphylococcus aureus mastitis. J. Dairy Sci. 89:1877-1895.

Barnouin, J., M. Chassagne, and I. Aimo. 1995. Dietary factors associated with milk somatic-cell counts in dairy cows in Brittany, France. Prev. Vet. Med. 21:299-311.

Beaudeau, F., and C. Fourichon. 1998. Estimating relative risk of disease from outputs of logistic regression when the disease is not rare. Prev. Vet. Med. 36:243-256.

Berry, E. A., and J. E. Hillerton. 2002. The effect of an intramammary teat seal on new intramammary infections. J. Dairy Sci. $85: 2512-2520$.

Black, R. T., C. T. Bourland, and R. T. Marshall. 1972. California Mastitis Test reactivity and bacterial invasions in quarters infected with Corynebacterium bovis. J. Dairy Sci. 55:1016-1017.
Capuco, A. V., A. Bright, J. W. Pankey, D. L. Wood, R. H. Miller, and J. Bitman. 1992. Increased susceptibility to intramammary infection following removal of teat canal keratin. J. Dairy Sci. 75:2126-2130.

Chassagne, M., J. Barnouin, and J. P. Chacornac. 1998. Biological predictors for early clinical mastitis occurrence in Holstein cows under field conditions in France. Prev. Vet. Med. 35:29-38.

De Vliegher, S., G. Opsomer, A. Vanrolleghem, L. A. Devriese, O. C. Sampimon, J. Sol, H. W. Barkema, F. Haesebrouck, and A. de Kruif. 2004. In vitro growth inhibition of major mastitis pathogens by Staphylococcus chromogenes originating from teat apices of dairy heifers. Vet. Microbiol. 101:215-221.

De Vliegher, S., H. W. Barkema, H. Stryhn, G. Opsomer, and A. de Kruif. 2005a. Impact of early lactation somatic cell count in heifers on milk yield over the first lactation. J. Dairy Sci. 88:938-947.

De Vliegher, S., H. W. Barkema, G. Opsomer, A. de Kruif, and L. Duchateau. 2005b. Association between somatic cell count in early lactation and culling of dairy heifers using Cox frailty models. J. Dairy Sci. 88:560-568.

Dingwell, R. T., K. E. Leslie, Y. H. Schukken, J. M. Sargeant, L. L. Timms, T. F. Duffield, G. P. Keefe, D. F. Kelton, K. D. Lissemore, and A. Conklin. 2004. Association of cow and quarter-level factors at drying-off with new intramammary infections during the dry period. Prev. Vet. Med. 63:75-89.

Dohoo, I., W. Martin, and H. Stryhn. 2003. Veterinary Epidemiologic Research. AVC Inc., Charlottetown, PEI, Canada.

Douglas, V. L., S. G. Fenwick, D. U. Pfeiffer, N. B. Williamson, and C. W. Holmes. 2000. Genomic typing of Streptococcus uberis isolates from cases of mastitis, in New Zealand dairy cows, using pulsedfield gel electrophoresis. Vet. Microbiol. 75:27-41.

Edwards, S. J., and G. W. Jones. 1966. The distribution and characters of coagulase-negative staphylococci of the bovine udder. J. Dairy Res. 33:261.

Fox, L. K., S. T. Chester, J. W. Hallberg, S. C. Nickerson, J. W. Pankey, and L. D. Weaver. 1995. Survey of intramammary infections in dairy heifers at breeding age and first parturition. J. Dairy Sci. 78:1619-1628.

Green, M. J., L. E. Green, G. F. Medley, Y. H. Schukken, and A. J. Bradley. 2002. Influence of dry period bacterial intramammary infection on clinical mastitis in dairy cows. J. Dairy Sci. 85:2589-2599.

Hintze, J. 2001. Number cruncher statistical systems (NCSS) and power analysis statistical systems (PASS). Kaysville, UT. www.ncss.com

Hogan, J. S., K. L. Smith, D. A. Todhunter, and P. S. Schoenberger. 1988. Rate of environmental mastitis in quarters infected with Corynebacterium bovis and Staphylococcus species. J. Dairy Sci. 71:2520-2525.

Huxley, J. N., M. J. Green, L. E. Green, and A. J. Bradley. 2002. Evaluation of the efficacy of an internal teat sealer during the dry period. J. Dairy Sci. 85:551-561.

Lam, T. J. G. M., Y. H. Schukken, J. H. vanVliet, F. J. Grommers, M. J. M. Tielen, and A. Brand. 1997. Effect of natural infection with minor pathogens on susceptibility to natural infection with major pathogens in the bovine mammary gland. Am. J. Vet. Res. 58:17-22.

Leigh, J. A. 1999. Streptococcus uberis: A permanent barrier to the control of bovine mastitis. Vet. J. 157:225-238.

Livestock Improvement Cooperation. 2004. 2003/2004 New Zealand Dairy Statistics. http://www.lic.co.nz/113_7.cfm. Livestock Improvement Cooperation, Hamilton, New Zealand.

Matthews, K. R., R. J. Harmon, and B. E. Langlois. 1991. Effect of naturally occurring coagulase-negative staphylococci infections on new infections by mastitis pathogens in the bovine. J. Dairy Sci. 74:1855-1859.

McDougall, S. 1999. Prevalence of clinical mastitis in 38 Waikato dairy herds in early lactation. N.Z. Vet. J. 47:143-149.

McDougall, S., T. J. Parkinson, M. Leyland, F. M. Anniss, and S. G. Fenwick. 2004. Duration of infection and strain variation in Streptococcus uberis isolated from cows' milk. J. Dairy Sci. 87:2062-2072. 
Meaney, W. J. 1981. Mastitis levels in spring-calving dairy heifers. Irish Vet. J. 35:205-209.

Munch-Peterson, E. 1970. Mastitis in bovine primiparae. Vet. Rec. 87:568.

Myllys, V. 1995. Staphylococci in heifer mastitis before and after parturition. J. Dairy Res. 62:51-60.

Nickerson, S. C., W. E. Owens, and R. L. Boddie. 1995. Mastitis in dairy heifers-Initial studies on prevalence and control. J. Dairy Sci. 78:1607-1618.

Oliver, S. P., M. J. Lewis, B. E. Gillespie, and H. H. Dowlen. 1992. Influence of prepartum antibiotic therapy on intramammary infections in primigravid heifers during early lactation. J. Dairy Sci. 75:406-414.

Oliver, S. P., M. J. Lewis, B. E. Gillespie, and H. H. Dowlen. 1997. Antibiotic residues and prevalence of mastitis pathogen isolation in heifers during early lactation following prepartum antibiotic therapy. J. Vet. Med. 44:213-220.

Oliver, S. P., M. J. Lewis, B. E. Gillespie, H. H. Dowlen, E. C. Jaenicke, and R. K. Roberts. 2003. Prepartum antibiotic treatment of heifers: Milk production, milk quality and economic benefit. J. Dairy Sci. 86:1187-1193.

Oliver, S. P., and B. A. Mitchell. 1983. Intramammary infections in primigravid heifers near parturition. J. Dairy Sci. 66:1180-1185.

Owens, W. E., S. C. Nickerson, and C. H. Ray. 2002. Effect of a pouron and fly tag insecticide combination in controlling horn flies and Staphylococcus aureus mastitis in dairy heifers. J. Anim. Vet. Adv. 1:200-201.

Pankey, J. W., S. C. Nickerson, R. L. Boddie, and J. S. Hogan. 1985. Effects of Corynebacterium bovis infection on susceptibility to major mastitis pathogens. J. Dairy Sci. 68:2684-2693.

Pankey, J. W., P. B. Pankey, R. M. Barker, J. H. Williamson, and M. W. Woolford. 1996. The prevalence of mastitis in primiparous heifers in eleven Waikato dairy herds. N.Z. Vet. J. 44:41-44

Rainard, P., and B. Poutrel. 1988. Effect of naturally occurring intramammary infections by minor pathogens on new infections by major pathogens in cattle. Am. J. Vet. Res. 49:327-329.

Rupp, R., F. Beaudeau, and D. Boichard. 2000. Relationship between milk somatic cell counts in the first lactation and clinical mastitis occurrence in the second lactation of French Holstein Cows. Prev. Vet. Med. 46:99-111.

Schreiner, D. A., and P. L. Ruegg. 2003. Relationship between udder and leg hygiene scores and subclinical mastitis. J. Dairy Sci. 86:3460-3465.

Schukken, Y. H., Y. T. Grohn, B. McDermott, and J. J. McDermott. 2003. Analysis of correlated discrete observations: Background, examples and solutions. Prev. Vet. Med. 59:223-240.

Todhunter, D. A., K. L. Smith, and J. S. Hogan. 1995. Environmental streptococcal intramammary infections of the bovine mammary gland. J. Dairy Sci. 78:2366-2374.

Trinidad, P., S. C. Nickerson, and T. K. Alley. 1990a. Prevalence of intramammary infection and teat canal colonization in unbred and primigravid dairy heifers. J. Dairy Sci. 73:107-114.

Trinidad, P., S. C. Nickerson, T. K. Alley, and R. W. Adkinson. 1990b. Efficacy of intramammary treatment in unbred and primigravid dairy heifers. J. Dairy Sci. 197:465-470.

Waage, S., H. R. Skei, J. Rise, T. Rogdo, S. Sviland, and S. A. Odegaard. 2000. Outcome of clinical mastitis in dairy heifers assessed by re-examination of cases one month after treatment. J. Dairy Sci. 83:70-76.

Waage, S., S. Sviland, and S. A. Odegaard. 1998. Identification of risk factors for clinical mastitis in dairy heifers. J. Dairy Sci. 81:1275-1284.

Williamson, J. H., M. W. Woolford, and A. M. Day. 1995. The prophylactic effect of a dry-cow antibiotic against Streptococcus uberis. N.Z. Vet. J. 43:228-234.

Woolford, M. W., J. H. Williamson, A. M. Day, and P. J. A. Copeman. 1998. The prophylactic effect of a teat sealer on bovine mastitis during the dry period and the following lactation. N.Z. Vet. J. $46: 12-15,18-19$.

Zadoks, R. N., H. G. Allore, H. W. Barkema, O. C. Sampimon, G. J. Wellenberg, Y. T. Grohn, and Y. H. Schukken. 2001. Cow- and quarter-level risk factors for Streptococcus uberis and Staphylococcus aureus mastitis. J. Dairy Sci. 84:2649-2663.

Zadoks, R. N., B. E. Gillespie, H. W. Barkema, O. C. Sampimon, S. P. Oliver, and Y. H. Schukken. 2003. Clinical, epidemiological and molecular characteristics of Streptococcus uberis infections in dairy herds. Epidemiol. Infect. 130:335-349. 